JPPUMA: Jurnal Ilmu Pemerintahan dan Sosial Politik UMA Uournal of Governance and Political Social

UMA), 8 (2) (2020): 124-133, DOI: https://doi.org/10.31289/ippuma.v8i2.3866

JPPUMA: Jurnal Ilmu Pemerintahan dan Sosial Politik UMA

(Journal of Governance and Political Social UMA)

Available online http://ojs.uma.ac.id/index.php/jppuma

\title{
COVID-19: Policy Evaluation to Protect Communities Through Social Safety Net
}

\author{
Nahot Tua Parlindungan Sihaloho, Marto Silalahi \& Bima Sujendra \\ Government Science, Faculty of Social and Political Sciences, \\ Universitas Tanjungpura, Indonesia
}

Received: June 12, 2020; Reviewed: June 15, 2020; Accepted: September 25, 2020

\section{Abstract}

This qualitative research seeks to evaluate the implementation of the Social Safety Net (SSN) program in North Sumatra as a result of the non-medical impact of the Covid-19 pandemic. In addition, this study also aims to identify vertical and horizontal obstacles, and to propose improvements in planning the next SSN implementation. This study uses secondary data presented in official government reports, research results, and the mass media. The collected data were analyzed following the steps described by Miles et al. (2014). The results showed that the distribution of SSN could not fully guarantee the protection and safety of the community's economy. Although SSN reduces the risk of economic downturn, SSN has not been able to reduce the conflicts that have so far occurred in North Sumatra. The implications of this study confirm three things. First, the implementation of SSN has not been successful as a whole because of the characteristics of the people who are not ready with the prerequisite situation to undergo a new normal. Second, the obstacles that arise are the occurrence of social conflicts, both vertically and horizontally. Third, it is necessary to carry out careful preparation in the first two stages of the standard implementation of public policies, namely agenda setting and drafting and consulting. However, public policy cannot one size fits all. Therefore, decision making needs to be based on the social characteristics of each region. Keywords: Social Safety Net; Covid-19; North Sumatra.

How to Cite: Sihaloho, N.T.P Silalahi, M \& Sujemdra, B. (2020). COVID-19: Policy Evaluation to Protect Communities Through Social Safety Net. JPPUMA: Jurnal Ilmu Pemerintahan dan Sosial Politik UMA (Journal of Governance and Political Social UMA), 8(2): 124-133

*Corresponding author:

E-mail: nahotsihaloho@fisip.untan.ac.id
ISSN 2549-1660 (Print)

ISSN 2550-1305 (Online) 


\section{PRELIMINARY}

Since the United Nations declared the 2019-nCoV (Covid-19) outbreak a global pandemic in March, there have only been two crucial issues that have become the priority of the Indonesian government, namely health issues and socio-economic problems. Apart from restricting access to and from Indonesian territory, the government also imposes other restrictions, such as Large-Scale Social Restrictions (LSSR) through Government Regulation No. 21 of 2020 as a follow-up to the ineffective Physical Distancing and Social Distancing. As a consequence, these restrictions have non-medical impacts, namely chaos in society at the lower class level and problems in the public sector that surrounds them, including public transportation, health services and education services. The final impact, of course, leads to an economic and social crisis. What's more, based on the distribution curve, Indonesia has not yet passed its peak.

As emphasized by the Ministry of Finance (2020c) in a press conference on April 1, the Covid-19 pandemic in all countries is causing economic pressure of $3 \%-16 \%$ of GDP. As a result, Indonesia's economic growth is at risk of falling to $2.3 \%$, while state revenue will fall by $10 \%$. For this condition, the Ministry of Finance (2020) states social safety nets as an alternative fiscal stimulus that is feasible to implement, together with tax incentives and medical facilities. This was realized with the issuance of Perppu No. 1 of 2020, which states that additional funds for mitigating Covid-19 through a social safety net are $110 \mathrm{~T}$ (Ministry of Finance, 2020b). The central government then coordinates with ministries, agencies and local governments so that the assistance is received by the community, either directly or indirectly (Ministry of Finance, 2020a).

Generally, the Social Safety Net (SSN) is realized through the distribution of Direct Cash Assistance (DCA), pre- employment programs, expansion of the Family Hope Program (HFP), Cash For Work (CFW), tax and electricity subsidies, and social assistance. However, the North Sumatra Provincial Government only provides two options; direct food assistance, or fund transfers (Satia, 2020a). This is not regulated in the North Sumatra Provincial Government Circular No. 800/16197 / BKD / II / 2020, which simply regulates the space for ASN and the people of North Sumatra before Eid. Therefore, the forms of assistance were varied and not standardized. In fact, the provincial government has also held a cheap market during May 17-21 so that affected residents are able to obtain basic foodstuffs at lower prices (Diskominfo Sumut, 2020).

Apart from the differences in characteristics between the people of North Sumatra and those in other provinces, the North Sumatra Provincial Government's policies do seem dichotomous and do not tend to prepare people to undergo the "new normal" phase. This policy is quite a contrast to policies in other provinces which are also red zones. The distribution of SSN in West Java Province, for example, is carried out in seven ways, including in the form of HFP expansion and the use of pre-employment cards (West Java Humas, 2020). Likewise, the distribution of SSN in East Java, which is more oriented towards meeting non-cash and non-food needs (DPMD Jatim, 2020).

In connection with the differences in policies above, as far as the author's research has been found, no research has been found that examines the distribution of SSN in North Sumatra Province in depth. The policy note from The Smeru Research Institute only recommends four alternatives (Yumna et al., 2020), which are not even in sync with the policies of the North Sumatra Provincial Government. The four alternatives include: a) listing the target beneficiaries of assistance, b) adapting pre-employment card training to needs, c) expanding the coverage of 
electricity assistance recipients, and d) ensuring the sustainability of MSEs. Even though a study on this matter is very urgent to do, especially the spread of Covid-19 in North Sumatra as of May 29, 2020 is still increasing (covid19.sumutprov.go.id, 2020).

Research by Susilawati et al. (2020) show that the economic sector is the most affected by the pandemic, followed by other sectors such as transportation, tourism, trade and health. Furthermore, according to Ansori's research report (2020) from The Habibie Center, the complexity of the problem during the Covid-19 pandemic has been exacerbated by the presence of various vertical and horizontal conflicts. This happens a lot in people who work in the informal sector, because it is not possible for them to fully follow the government's appeal. Theoretically, these conflicts will develop into mass violence when the follow-up on SSN so far is not based on the results of evaluative research.

Therefore, the urgency of this research lies in the effectiveness and the factors that influence the success of SSN in North Sumatra. This research, in the end, was conducted with reference to the research question: how was the success of SSN in North Sumatra as a mitigation of the impact of the Covid-19 pandemic? Answering these research questions can contribute to evaluation materials, so that they can be used by the government at the central, regional, and even government at the village / kelurahan level. The results of this study provide scientific information about the effectiveness of SSN in North Sumatra along with their supporting and inhibiting factors. Practically, the results of this study can be referred to by other researchers outside North Sumatra in order to find solutions to problems with the same characteristics as the situation in North Sumatra.

The Social Safety Net (SSN) analogy is taken from a situation where a person is walking at a height, who then falls suddenly. The function of the SSN is to catch the person so that he does not hit the ground and is badly injured (Paitoonpong et al., 2008). Referring to this reasoning, the concept of SSN in mitigating Covid-19 was used to overcome the effects of the LSSR in the form of an increase in poverty, social crises and economic crises. This is because, although it does not widen social disparities, LSSR results in many cases of termination of employment and a weakening of the economy of informal sector workers. In practice, this has resulted in mass unemployment and the potential for social conflict.

In Southeast Asia (including Indonesia), the implementation of SSN has indeed been popular since the economic crisis in 1997-1998 as a national financial disaster mitigation procedure (Sumarto et al., 2002). Initially, SSN was formulated to meet three objectives; poverty alleviation, a more politically acceptable adjustment program, and institutional reform (Paitoonpong et al., 2008). However, in its development, SSN is more focused on achieving the first goal. All resources are prepared to help the poor and the new poor to be able to survive the crisis period safely.

At that time, according to Sumarto (2005), the SSN program was classified as successful because it was specifically determined to: 1) ensure the availability of affordable food prices, 2) increase household purchasing power through job creation, 3) provide access to critical social services, especially health and education, 4) maintaining local economic activity through regional grants and small-scale credit.

Conceptually, the principles of SSN distribution during the 1998 crisis could indeed be easily adopted to mitigate Covid19 today. However, experience also notes that mass unemployment and social conflict are inevitable if the distribution of SSN is not on target. This is evidenced by the research of Cherrier et al. (2011) which shows that this method is actually classified 
as effective in saving the community's economy during difficult times, but it will be a waste if the distribution is not on target. Cherrier et al. (2011) gave an example of how the distribution of SSN in Mali, which could not meet the needs of the community.

Based on the experience in Mali, Cherrier et al. (2011) suggest that some of the distribution of SSN should be realized in the form of programs that can increase community competence. Therefore, the government needs to: (1) strengthen the strategic, institutional and financial frameworks to design, implement and monitor SSN; (2) increasing the effectiveness of the SSN system by strengthening existing programs and designing new programs.

Related to this, the North Sumatra Provincial Government's decision to split the SSN into cash assistance and direct food assistance could be a form of distribution that is not on target. Because, people are now forced to enter and follow the new normal. This is the fundamental difference between the 1998 crisis and the crisis caused by the Covid-19 pandemic.

Therefore, it is important to look at the affirmation of Hansnata et al. (2013), that poverty alleviation programs such as SSN and poor rice should be viewed from a micro perspective according to community conditions and community needs in the future. Moreover, according to the conclusions of Ananta \& Siregar's (1999) study on the experience of implementing SSN during the 1998 crisis, inaccurate economic indicators to measure social impacts will undermine the effectiveness of SSN policies. This is confirmed by the research of Sumarto et al. (2004), who stated that the single most successful attempt during the 1998 crisis was the subsidized rice program.

\section{RESEARCH METHODS}

This qualitative study used a literature review design. The literature review design was chosen because of its effectiveness in facilitating researchers to map evidence bases accurately and accurately, measure the quality of evidence, and then compile a synthesis as research findings (Gough, 2007). Using such trends, researchers are able to answer research problems based on the identification of data in the literature selected purposively (Bhimani et al., 2019).

This research was conducted based on the six main steps introduced by the EPPICenter (2006) and Harden \& Thomas (2007). First is the formulation of research problems, which in this study is the distribution of SSN in North Sumatra which according to experience in several places is not on target so it needs to be evaluated. The second is the determination of the integration criteria (scope of review and development of review protocol). The inclusion criteria specified in this study include: 1) literature must contain SSN Covid-19 in North Sumatra, 2) literature is not opinion writing or fiction, 3) literature published in 2020, and 4) literature is qualitative and quantitative in nature. The third is a comprehensive search online using the keyword "Covid-19 social safety net in North Sumatra" and other relevant or synonymous keywords. A search at this stage resulted in 34 literature, consisting of literature in .pdf format documents and online newspapers. All documents and newspaper links that have been collected are stored in the researcher database, and then proceed to the fourth stage, which is filtering the literature according to the inclusion criteria set. Because this phase is also used to assess the feasibility of the literature (quality assessment), several literatures were eliminated so that 18 literatures were obtained.

As the fifth and sixth stages, data in the 18 literature were extracted and analyzed following the steps proposed by Miles et al. (2014), namely: condensation data, display data, and conclusion drawing. Thus obtained several research findings 
drawn from the conclusions of data analysis as described in the Results and Discussion section of this scientific article.

\section{RESULTS AND DISCUSSION}

\section{Summary of SSN Policy Evaluation}

In principle, what the public should do to reduce the risk of the spread of Covid-19 infection is not to attend crowds, such as: music festivals, conferences, cultural celebrations, political events, and other activities that allow social contact. Medically, the procedure is highly recommended because respiratory infections are easy to occur at such events (Ebrahim et al., 2020). However, socioeconomically, the people of North Sumatra have difficulty accepting these recommendations. Mainly people with typical jobs in the informal sector; they continue to receive SSN distribution from the North Sumatra Provincial Government through the district and village governments. However, in practice, they also continue to work outside the home. They, in this case, are still at risk of social interaction and being exposed to Covid-19.

The Central Statistics Agency (CSA) (2018), referring to the 2018 Susenas data, notes that $30.21 \%$ of households in North Sumatra buy poor rice. CSA data (2018) also shows that the average number of households in North Sumatra who receive a Social Protection Card (SPC) or a Prosperous Family Card (PFC) is $15.38 \%$. These figures are an indication of the large number of poor people in North Sumatra. This means that it is very common if the provision of SSN to mitigate the Covid-19 pandemic in North Sumatra is still inadequate to save the people's economy. At least that is the conclusion based on statistical data, that the people's economy is indeed low.

Although the Ministry of Home Affairs Work Team (2020) stated that nonpharmaceutical intervention is the best form of intervention to slow down the transmission of Covid-19 at the community level, it does not mean that the people of North Sumatra are able to fulfill this assumption. That is, the SSN distributed in North Sumatra is not sufficient to meet the needs of the community during the implementation of the cluster system which was in effect since 1 May 2020, especially for people who belong to special groups; elderly and people with disabilities. They are a high-risk group because their mobility is very limited and they have experienced social isolation since before and during the Covid-19 pandemic. Therefore, SSN did not solve their problems (TNP2K, 2020).

\section{Vertical and Horizontal Barriers}

The evaluation above highlights the existence of several conflicts that have occurred even though the SSN for Covid-19 mitigation has been distributed. Vertical conflict refers to conflict between the community and the government or that involves elements of government and all forms of apparatus. The horizontal conflict refers to conflict between communities.

The first vertical conflict is the conflict between the security forces and the people who work in the informal sector, as stated by Pasaribu (2020). The characteristic characteristic of this type of worker is daily income. Therefore, restrictions on activities outside the home and calls to stay at home pose a dilemma, even though in the end they are violated and come into conflict with the security forces or law enforcement officers who raided them to mitigate Covid19. Considering that this type of conflict often occurs in various regions, it is better if this kind of conflict is resolved by prioritizing the Alternative Dispute Resolution (ADR) approach. This means that the security apparatus should prioritize negotiation and dialogue to avoid physical violence. If necessary, the apparatus coordinates with the local government to provide insight into the management of SSN.

The second vertical conflict is indicated by an increase in the crime rate 
during the Covid-19 pandemic. There are at least two main assumptions to explain this increase in crime. First, the Covid-19 mitigation policy, which relies heavily on restricting activities outside the home, does have a huge effect on the economic stability of the lower class. As a result, crime was chosen as an alternative shortcut (Billiocta, 2020; Ruler, 2020). Second, the government has released more than 30,000 prisoners, which the government says is one of the efforts to mitigate Covid-19 (Kompas.com, 2020b). Those who were released due to assimilation did not only have no income and permanent jobs when they left prison. But at the same time, they are also immediately faced with a difficult situation to get a job because of the Covid19 pandemic policy. Finally, they returned to committing crimes as a shortcut to survive (Kompas.com, 2020a). Unlike the first vertical conflict, the emphasis on the conflict resolution process is more towards the rule of law approach rather than the ADR approach.

The third vertical conflict is the problem of the distribution of social assistance itself. The source of this conflict in particular refers to the distribution of social assistance that is uneven and not well targeted. Examples are as mentioned by Pencawan (2020), Sianturi (2020), Munte (2020), Sianturi (2020a) and Satia (2020b). Generally, an element of this conflict is overlapping data on recipients of social assistance. This can occur due to data falsification and human error during data collection (including data collection instruments and actors who collect data / surveyors). Regarding the handling of this conflict, the government is more suitable to use the ADR approach.

In contrast to vertical conflicts which tend to be political and economic in nature, horizontal conflicts tend to be ethical. The first horizontal conflict was the refusal to bury the bodies of Covid-19 patients. Several examples of this rejection occurred in Medan (Widyastuti, 2020), in Tanah Karo
(Kumparan.com, 2020), and in Binjai (Gunawan, 2020). Although it seems that they are not related to SSN, the medical vulnerability of the elderly makes this problem more complex and interrelated. This is because the inadequate SSN to meet the needs of the elderly increases the chances of the elderly to die while exposed to Covid-19. This means that the chances of them surviving Covid-19 infection are very low. In other words, this will further increase the risk of horizontal conflict as experienced in various regions in North Sumatra.

The second horizontal conflict is a feud between workers / employees and employers regarding the rights of workers / employees who have experienced work termination as a result of the Covid-19 pandemic. As confirmed by the Manpower Office of North Sumatra Province, there are at least 14 thousand workers affected by the Work termination in North Sumatra (CNN, 2020). In order to overcome this, the commonly used approach should refer to the Manpower Law No. 13 of 2003, prioritizing the ADR approach.

\section{Improved SSN Implementation}

In general, the above conflicts clearly hamper the government's performance in mitigating Covid-19. Given the large number of responsibilities during this pandemic period, handling should seriously consider the cost and benefits (Ansori, 2020). Therefore, SSN as one of the social assistance programs should be implemented according to standard stages: agenda setting, drafting and consulting, coordination and implementation, and monitoring and evaluation. Each of these phases must involve key actors in charge, namely the political elite at the national and local levels (Datta et al., 2014). In the first and second stages, in order to provide protection to workers as well as employers, it is necessary to carry out a clear mapping and distribution of power between the central government and local governments. 
Although in the future there will be rejection of government regulations, at least this will reduce the severity of government losses (Mahy, 2020).

The method of saving the community's economy using SSN does seem a dilemma. On the one hand, the economic trend in North Sumatra Province has tended to increase, and it is even predicted to experience an acceleration in 2013 and the following years. This is an indication of an increase in people's standard of living (BI, 2013). But on the other hand, currently people are receiving SSN assistance that does not educate (prepare) to face the new normal. Even so, however, unconditional cash assistance or income security is needed as a form of handling a pandemic in a socio-economic aspect. Because by doing so, people can maintain their purchasing power, maintain a decent standard of living, and realize people's happiness.

Considering the above vision and the socio-economic conditions of the people of North Sumatra, it seems that the two cash program schemes offered by prakarsa.org (2020) deserve attention and consideration. The two cash cash program schemes are: (1) the minimum scheme, namely Corona Cash Assistance (Batuna), which is aimed at 10 million poor households for six months (AprilSeptember 2020) with a nominal value of 2 million per household / month; (2) the maximum scheme, namely the Universal Income Guarantee (Jamesta), which is intended for all citizens of productive age and the elderly for three months (AprilJune 2020) with a nominal value of 500,000 per individual / month. However, even one of these programs must be pursued following the steps proposed by Datta et al. (2014) so that distribution is right on target and efficient. As with the general guidelines from the Ministry of Home Affairs, the implementation of Covid-19 response measures by local governments must consider the following: a) local characteristics, b) disease transmission mechanisms, c) demographic factors, and d) the level of public health as well as the capacity of available health workers (Ministry of Home Affairs Work Team, 2020).

\section{CONCLUSION}

The success of mitigating the Covid-19 pandemic in North Sumatra through social safety nets is not yet certain, especially since the secondary data collected in this study is not final (still changing; dynamic). However, at least it can be emphasized that the SSN has not yet overcome new social inequalities, such as: crime, the economic needs of informal workers, and social protection for special groups. Predictive assumptions that can be put forward are the reduction in inequality along with the implementation of ADR and the use of the rule of law for conflict resolution.

The identification in this study confirms that the success of the distribution of SSN in North Sumatra is largely influenced by the socio-economic situation of the community itself. This situation in turn creates vertical and horizontal barriers as discussed above. Thus the results of this study have direct implications as material for correction and evaluation of the first two stages in the standard implementation of public policies in North Sumatra, namely agenda setting and drafting and consulting.

\section{ACKNOWLEDGEMENT}

The author's gratitude goes to the Dean of FISIP, Tanjungpura University, Mr. Dr. H. Martoyo, M.A, Vice Dean I Mr. Dr. Herlan, Deputy Dean II Mr. Dedi Kusnadi, and Deputy Dean III Mr. M. Sabran Achyar, M.Si who have supported the implementation of research and manuscript writing.

\section{REFERENCES}

Ananta, A., \& Siregar, R. (1999). Social safety nets in Indonesia: Objectives and shortcomings. 
ASEAN Economic Bulletin, 16(3), 344-359. https://doi.org/10.1355/ae16-3e

Ansori, M. H. (2020). Asesmen dan mitigasi konflik di tengah pandemi Covid-19 di Indonesia (Issue 16).

https://www.habibiecenter.or.id/img/publi cation/9dfd96ff764ad0c165392a853af2b79 9.pdf

Bhimani, H., Mention, A. L., \& Barlatier, P. J. (2019). Social media and innovation: A systematic literature review and future research directions. Technological Forecasting and Social Change, 144, 251-269. https://doi.org/10.1016/j.techfore.2018.10. 007

BI. (2013). Kajian ekonomi regional provinsi Sumatera Utara: Triwulan IV 2012. Kantor perwakilan BI wilayah IX.

Billiocta, Y. (2020). Polisi Ungkap 5 Daerah di Sumut Diduga Terkait Penyelewengan Bansos Covid19. Merdeka.Com. https://www.merdeka.com/peristiwa/polisi -ungkap-5-daerah-di-sumut-diduga-terkaitpenyelewengan-bansos-covid-19.html

BPS. (2018). Statistik kesejahteraan rakyat Provinsi Sumatera Utara. BPS Sumatera Utara.

Cherrier, C., del Ninno, C., \& Razmara, S. (2011). Mali social safety nets. The World Bank.

CNN. (2020). Imbas corona, 14 ribu pekerja alami PHK di Sumut. Cnnindonesia.Com. https://www.cnnindonesia.com/ekonomi/2 0200508185900-92-501467/imbas-corona14-ribu-pekerja-alami-phk-di-sumut

Covid19.sumutprov.go.id. (2020). Gugus tugas percepatan penanganan Covid-19. Sumutprov.Go.Id. http://covid19.sumutprov.go.id/

Datta, A., Febriany, V., \& Susilatuti, D. (2014). Social assistance policymaking in Indonesia: Opportunities for, and constraints to, promoting reform (Issue January 2014). https://doi.org/10.13140/RG.2.1.1976.6008

Diskominfo. (2020). Bantuan jaring pengaman sosial mulai disalurkan. Sumutprov.Go.Id. https://diskominfo.sumutprov.go.id/artikel2729-bantuan-jaring-pengaman-sosialmulai-disalurkan.html

dpmd. (2020). Jaring pengaman sosial pemerintah Provinsi Jawa Timur. Jatimprov.Go.Id. https://dpmd.jatimprov.go.id/homemainmenu-1/90-berita/1367-jaringpengaman-sosial-pemerintah-provinsi-jawatimur

Ebrahim, S. H., Ahmed, Q. A., Gozzer, E., Schlagenhauf, P., \& Memish, Z. A. (2020). Covid-19 and community mitigation strategies in a pandemic. The BMJ, 368, 1-2. https://doi.org/10.1136/bmj.m1066
EPPI-Centre. (2006). EPPI-Centre methods for conducting systematic reviews. Social Science Research Unit, Institute of Education, University of London.

Gough, D. (2007). Weight of evidence: A framework for the appraisal of the quality and relevance of evidence. Research Papers in Education, 22(2),

213-228. https://doi.org/10.1080/026715207012961 89

Gunawan, H. (2020). Lagi, penolakan pemakaman korban Covid-19, warga Mencirim lempari ambulans yang sedang cek pemakaman. Tribunnews.Com. https://www.tribunnews.com/regional/202 0/05/01/lagi-penolakan-pemakamankorban-covid-19-warga-mencirim-lempariambulans-yang-sedang-cek-pemakaman

Hansnata, E., Resosudarmo, B. P., \& Oka, D. I. B. (2013). Does regional govenment spending matter to regional poverty dynamics? In Regional development, natural resources and public goods in Indonesia during the global financial crisis. UI Press.

Harden, A., \& Thomas, J. (2007). Methodological issues in combining diverse study types in systematic reviews. International Journal of Social Research Methodology, 8(3), 257-271. https://doi.org/10.1080/136455705001550 78

Humas. (2020). Lima skema jaring pengaman sosial di Jabar. Jabarprov.Go.Id. https://jabarprov.go.id/index.php/news/37 418/2020/04/15/Lima-Skema-JaringPengaman-Sosial-di-Jabar

Kemenkeu. (2020a). Menjaga ekonomi Indonesia terhadap dampak negatif pandemik Covid-19. Kemenkeu.Go.Id.

https://www.kemenkeu.go.id/publikasi/siar an-pers/siaran-pers-menjaga-ekonomiindonesia-terhadap-dampak-negatifpandemik-covid-19/

Kemenkeu. (2020b). Pemerintah terbitkan Perppu untuk tangani dampak ekonomi akibat Covid19. Kemenkeu.Go.Id. https://www.kemenkeu.go.id/publikasi/siar an-pers/siaran-pers-pemerintah-terbitkanperppu-untuk-tangani-dampak-ekonomiakibat-covid-19/

Kemenkeu. (2020c). Press Conference - Langkah penguatan perlindungan sosial dan stimulus ekonomi menghadapi dampak Covid-19 (Issue 1 April). https://www.kemenkeu.go.id/media/14790 /materi-konferensi-pers-1-april-2020.pdf

Kompas.com. (2020a). Mengapa napi asimilasi kembali berbuat kriminal? Ini analisisnya. Kompas.Com. https://www.kompas.com/tren/read/2020/ 
04/19/130400565/mengapa-napi-asimilasikembali-berbuat-kriminal-ini-analisisnya?page $=3$

Kompas.com. (2020b). Pembebasan 30.000 narapidana akibat wabah virus corona. Kompas.Com.

https://nasional.kompas.com/read/2020/0 4/01/09314561/pembebasan-30000narapidana-akibat-wabah-virus-corona

Kumparan.com. (2020). Warga di Tanah Karo, Sumut, tolak pemakaman jenazah PDP Covid19.

Kumparan.Com.

https://kumparan.com/kumparannews/war ga-di-tanah-karo-sumut-tolak-pemakamanjenazah-pdp-covid-19-1tUve6QQrqY/full

Mahy, P. (2020). COVID-19 and labour law: Indonesia. Italian Labour Law E-Journal, 13(1), 1-10. https://doi.org/10.6092/issn.15618048/10937

Miles, M. B., Huberman, A. M., \& Saldana, J. (2014). Qualitative data analysis: $A$ methods sourcebook (3rd ed.). Sage Publication. https://doi.org/10.1080/014052879001040 6

Mistar, H. (2020). Tindak Kejahatan Meningkat di Medan.

Mistar.Id.

https://www.mistar.id/hukum-

peristiwa/tindak-kejahatan-meningkat-dimedan/

Munte, T. (2020). Data Penerima Bansos Covid-19 di Sumut Belum Beres - Gugus Tugas Percepatan Penanganan Covid-19 Sumatera Utara tengah memvalidasi data penerima bantuan JPS. Tagar.Id. https://www.tagar.id/datapenerima-bansos-covid19-di-sumut-belumberes

Paitoonpong, S., Abe, S., \& Puopongsakorn, N. (2008). The meaning of "social safety nets." Journal of Asian Economics, 19(5-6), 467473.

https://doi.org/10.1016/j.asieco.2008.09.01 1

Pasaribu, O. (2020). Kisruh soal BLT, Warga Bentrok dengan Polisi hingga 2 Mobil Dibakar. Kompas.com.

https://regional.kompas.com/read/2020/0 6/29/21082021/kisruh-soal-blt-wargabentrok-dengan-polisi-hingga-2-mobildibakar?page=all

Pencawan, Y. (2020). Penyaluran Bantuan JPS Covid19 Sumut belum Tuntas. Media Indonesia. https://mediaindonesia.com/read/detail/32 3343-penyaluran-bantuan-jps-covid-19sumut-belum-tuntas

Prakarsa.org. (2020). Prakarsa policy brief-Program tunai di era Covid-19: bantuan tunai korona atau jaminan penghilan semesta (Issue April, pp. 1-4). Prakarsa. https://doi.org/10.6092/unibo/amsacta/62 47

Satia. (2020a). GTTP Covid19 Sumut salurkan jaring pengaman sosial di empat daerah. Tribunnews.Com. https://medan.tribunnews.com/2020/05/1 3/gttp-covid19-sumut-salurkan-jaringpengaman-sosial-di-empat-daerah

Satia. (2020b). KPK Terima 303 Laporan Keluhan Masyarakat Terkait Penyaluran Bansos, Sumut 21 Laporan. Tribunnews.Com. https://medan.tribunnews.com/2020/06/1 3/kpk-terima-303-laporan-keluhanmasyarakat-terkait-penyaluran-bansossumut-21-laporan

Sianturi, A. H. (2020a). Di Sumut, Warga yang Rumahnya Permanen Terima Bansos. Berita Satu. https://www.beritasatu.com/jeismontesori/nasional/634805/di-sumutwarga-yang-rumahnya-permanen-terimabansos

Sianturi, A. H. (2020b). Pemprov Sumut Gandeng TNI/Polri untuk Validasi Data dan Distribusi Bantuan. Berita Satu. https://www.beritasatu.com/jeismontesori/nasional/626975/pemprovsumut-gandeng-tnipolri-untuk-validasi-datadan-distribusi-bantuan

Sumarto, S. (2005). Policy brief 5: Social safety netsIndonesia. In Overseas Development Institute (Issue February). www.odi.org.uk/interregional_inequality

Sumarto, S., Suryahadi, A., \& Widyanti, W. (2002). Designs and implementation of the Indonesian social safety net programs. The Developing Economies, 60(1), 3-31.

Sumarto, S., Suryahadi, A., \& Widyanti, W. (2004). Assessing the impact of Indonesian social safety net programmes on household welfare and poverty dynamics. In European Journal of Development Research (Vol. 17, Issue 1). https://doi.org/10.1080/095788105000667 46

Susilawati, Falefi, R., \& Purwoko, A. (2020). Impact of COVID-19's pandemic on the economy of Indonesia. Budapest International Research and Critics Institute (BIRCI-Journal): Humanities and Social Sciences, 3(2), 11471156. https://doi.org/10.33258/birci.v3i2.954

Tim Kerja Kementerian Dalam Negeri. (2020). Pedoman umum menghadapi pandemi covid19 bagi penmerintah daerah: Pencegahan, pengendalian, diagnosis dan manajemen. Kementrian Dalam Negeri. https://doi.org/10.1017/CB097811074153 24.004

TNP2K. (2020). Lifecycle social protection assessment: Elderly vulnerability and social 
JPPUMA: Jurnal Ilmu Pemerintahan dan Sosial Politik UMA (Journal of Governance and Political Social UMA), 8 (2) (2020): 124-133

protection during Covid-19 pandemic. Tim Nasional Percepatan Penanggulangan Kemiskinan.

Widyastuti, I. (2020). Warga diimbau tidak tolak penguburan jenazah pasien Covid-19. RRI.co.id.

https://rri.co.id/medan/daerah/815082/wa rga-diimbau-tidak-tolak-penguburanjenazah-pasien-covid-19

Yumna, A., Arfyanto, H., Bima, L., \& Bachtiar, P. P. (2020). Jaring pengaman sosial dalam krisis COVID-19: Apa yang saat ini perlu dilakukan oleh pemerintah? (Issue 3). www.smeru.or.id. 